\title{
Factors Influencing on Job Preference among Shariah Banking Student
}

\author{
Rosana Eri Puspita ${ }^{*}$ \\ ${ }^{1}$ IAIN Salatiga
}

Submitted: February 22, 2019, Accepted: August 19, 2019, Published: August 22, 2019

\begin{abstract}
The aim of this study is to predict factors influencing in job preference among Shariah Banking Student at disruption era. There are two variables to predict the factors, knowledge about sharia banking career and attitude. This study used a quantitative approach and online survey as the data collection technique. The result showed that intention is influenced by attitude and knowledge. This research provided a suggestion for managers of Islamic banking programs to carry out two approaches to marketing it, namely the consumer approach and product approach. The consumer approach was carried out by transferring knowledge about broader job prospects in this era and conducting market sensing. While the product approach was done by compiling a curriculum that is always updated with the needs of markets that are moving rapidly in this era. This study is limited to only on sharia banking student. The limitation of this study is the absence of testing of factors other than knowledge and attitudes that contribute to predicting intentions.
\end{abstract}

Keywords: knowledge; attitude; intention; sharia banking

\begin{abstract}
Abstrak
Tujuan dari penelitian ini adalah memprediksi faktor yang mempengaruhi preferensi pekerjaan pada mahasiswa Perbankan Syariah di era disrupsi. Ada dua variabel untuk memprediksi faktor-faktor tersebut, yaitu pengetahuan tentang karir kerja perbankan syariah di era dan sikap. Pendekatan kuantitatif diadopsi dalam penelitian ini. Pengumpulan data dilakukan dengan survei online. Penelitian ini menggunakan pendekatan kuantitatif dengan mengetahui pengaruh antar variabel. Hasil penelitian menunjukkan bahwa niat dipengaruhi oleh sikap dan pengetahuan. Penelitian ini memberikan saran bagi manajer program perbankan syariah untuk melakukan dua pendekatan untuk memasarkannya, yaitu pendekatan konsumen dan pendekatan produk. Pendekatan konsumen dilakukan dengan mentransfer pengetahuan tentang prospek pekerjaan yang lebih luas di era ini dan melakukan penginderaan pasar. Sedangkan pendekatan produk dilakukan dengan menyusun kurikulum yang selalu diperbarui sesuai dengan kebutuhan pasar yang bergerak cepat di era ini. Penelitian ini terbatas hanya pada siswa perbankan syariah. Keterbatasan penelitian ini adalah tidak adanya pengujian faktor selain pengetahuan dan sikap yang berkontribusi untuk memprediksi niat.
\end{abstract}

Kata Kunci: pengetahuan; sikap; niat; bank syariah

* Corresponding author
E-mail : rosana.eri.p@iainsalatiga.ac.id ${ }^{1}$

ISSN 2087-7013

ISSN 2527-8304 


\section{INTRODUCTION}

In the digital era, bank's customers rarely visit bank offices because customers prefer to transact through electronic channels (e-channels) such as ATMs, mobile banking, or internet banking (Apriyani, 2016). Such a condition makes the productivity of bank offices questionable, including bank employees in bank offices. Such conditions make inefficiency in labor costs.

In 2017, the number of bank workers in Indonesia has decreased compared to the previous year. In 2017 the number of Danamon Bank employees decreased as much as 6,021 people from 2016 and was also decreased as much as 4,391 people from 2015. In 2017, Adira Finance also experienced a decrease in the number of employees at much as 7,609 people compared to the previous year. The decline in the number of bank employees was also experienced by Mandiri Bank, BNI, BTPN, and Maybank (Laucereno, 2018).

Meanwhile, Indonesia has many public and private universities majoring in Islamic banking and conventional banking. Some online news mentioned that the Sharia Banking Study Program remains the most favorite major for society when they continue their study. Sharia banking study program was ranked second in the most registrant category in UIN Sunan Kalijaga (Rochmatin, 2018). In addition, Sharia Banking is the most favorite study program in SPAN PTKIN (Liputan6.com, 2018).

With a large number of students owned by PTKIN in Indonesia especially Sharia banking majors, a number of questions then arose, such as; how is the students' knowledge about sharia banking, career prospect in the digital era, and predicting the students' intention to be a banker in the future. Predicting intentions is very important to this study because behavior to be a banker triggered by the intention. This study will directly affect the marketing of sharia banking majors. This research is also important as the reference in making policies in the sharia banking program.

The new thing offered by this study is the newest condition of the environment of the research object. The era of disruption has changed all conditions in the business sector, including the banking business. Transformation in business conditions will certainly change various aspects of the company's operations, including the intention to be involved in that part of the business.

\section{RESEARCH METHODOLOGY}

The approach used in this study is quantitative. The stages used in this study are; writing hypotheses, deciding the most suitable statistical tests, deciding the level of significance, calculating the difference in values, getting the value of critical testing, and interpreting the results of the study (Cooper \& Schindler, 2014).

Data collection is done by online surveys. The research instrument was a questionnaire distributed to the students of sharia banking programs. The sampling in this study was categorized as nonprobability because it did not have a sampling frame. Sampling was taken by purposive sampling, with judgment sampling type. Purposive sampling is a nonprobability sample chosen according to the specified criteria while a judgment sample will occur when a researcher chooses sample members to fulfill several 
criteria (Cooper \& Schindler, 2014).

There were three criteria of the samplings; First, respondents were generation Z. This generation was born between 1995 to 2009. The labels attached to this generation were digital native generation, honest, humorous, respecting diversity, and information become an important part of their lives (Hawkin \& Mothersbough, 2014). Second, the respondents in this study were internet users. This was because the data collection method used in this study was carried out through an online survey. Third, the respondents of this study were the students of sharia banking program. Fourth, the respondents must not work at the bank yet since the research focuses on the study of intentions.

The table below contains specific information about the respondents with 121 respondents in total. From the data of respondents based on gender, there are $81 \%$ of respondents are female and $19 \%$ are male. From Table 1, respondents with a bachelor's level of education were $81.8 \%$ and their diploma's level of education was $18.2 \%$. Students in $1^{\text {st }}$ semester were $38.8 \%, 3^{\text {rd }}$ semester was $13.2 \%, 5^{\text {th }}$ was $42.2 \%$ and $7^{\text {th }}$ was $5.8 \%$.

Table 1. Demographic Information of the Respondents

\begin{tabular}{lr}
\hline Demographic & Percentage \\
\hline Gender & \\
Female & $81 \%$ \\
Male & $19 \%$ \\
School Program & \\
Bachelor & $81.8 \%$ \\
Diploma & $18.2 \%$ \\
Semester & \\
1 st & $38.8 \%$ \\
$3^{\text {rd }}$ & $13.2 \%$ \\
$5^{\text {th }}$ & $42.2 \%$ \\
$7^{\text {th }}$ & $5.8 \%$ \\
\hline
\end{tabular}

Before testing hypotheses, this study has passed the validity and reliability test of the research instrument. The purpose of testing the validity is to see the accuracy in measurement. Construct validity was carried out by using factor analysis. The factor analysis test was used to get the value of the Keiser-Meyer-Olkin (KMO) test and Bartlett Sphericity test results. KMO values were categorized into three. KMO values of 0.5-0.7 were categorized as moderate, 0.7 were categorized as good, and values above 0.9 were very good (Li, Zhang, Tong, Tong, \& Liu, 2011).

The test results of KMO and Barlett Sphericity in 121 respondents were presented in Table 2. From the tests, the KMO value is 0.501 which was categorized as medium value. The value of 0.501 was higher than the minimum limit of the value which was of 0.5 , this could be interpreted that the analysis of the factor is suitable to test the data. The significance value of the Bartlett of sphericity test is 0.001 , because $\alpha=0.005>0.000$, it means that the matrix was not an identity matrix so that factor analysis can be used. 
Table 2. Sample Adequacy KMO and Bartlett Sphericity

\begin{tabular}{lr}
\hline Testing & Value \\
\hline Sample Adequacy KMO & 0.501 \\
Bartlett of Sphericity & $0.000^{*}$ \\
\hline *significant at $\alpha=0.05$ &
\end{tabular}

Convergent validity was fulfilled if the loading value on each indicator was more than 0.7 with a significant p-value $<0.05$ (Hair, Black, Babin, Anderson, \& Tatham, 2006). If there were indicators below 0.4 , it must be issued from the construct and the indicator with a value of 0.4-0.7 should also be issued in order to increase the Average Variance Extracted (AVE). From the test results presented in Table 3, there was no indicator that has a loading value of less than 0.7 so that it can be called valid.

Reliability was measured by calculating the value of Cronbach alpha. Reliability was built by consistency testing and stability (Sekaran \& Bougie, 2016). Consistency was indicated by how well items to measure concepts when it was used together in a device.

Table 3. Convergent Validity and Reliability Test

\begin{tabular}{rr} 
Item & Loading \\
\hline
\end{tabular}

Knowledge $(\mathrm{CR}=0.814)^{* *}$

Knowing that the conditions of employment in the field of Islamic banking in the current era of disruption differ from the previous era $0.780^{*}$

Knowing that the services offered by Islamic banking in the era of technology-based disruption are different from the previous era which tended to be manual

Knowing that operations in Islamic banking in the era of disruption that tend to be technology-based are different from those in the previous era which tended to be manual

Knowing that technology can help a lot in Islamic banking in the current era of disruption

Attitude $(\mathrm{CR}=0.866)^{* *}$

A career in the world of Islamic banking in the current era of disruption is not very profitable

A career in the world of Islamic banking in the era of disruption is not very good

A career in the world of Islamic banking in the era of disruption is not very valuable for the future

A career in the world of Islamic banking in the era of disruption is not very interesting

Intention $(\mathrm{CR}=0.888)^{* *}$

The intention not to be a sharia banker

Don't really want to be a sharia banker even though you are in the Islamic banking department

Don't really want to be a sharia banker $0.902 *$

\footnotetext{
*valid (loading $>0.7$ )

**reliable (Cronbach alpha $>0.7$ )
} 
Table 3 presents the results of the reliability test with the results of calculating the Cronbach alpha value. From the testing of three variables, the Cronbach alpha value was obtained above all 0.7 so that it can be concluded that the measuring instruments used in this study were reliable.

Knowledge of an object influences the attitude towards the object (Agueria, Terni, Baldovino, \& Civit, 2018; Cheah, Liang, \& Liang, 2015; Hinduan, Suherman, Pinxten, Alisjahbana, \& Hospers, 2013; Teng \& Wang, 2015). Changes in the information received by someone will cause a change in the attitude of the person (Hartogh, 2014). Based on those previous studies, this study develops a hypothesis that the knowledge of Sharia banking students about employment conditions has a positive effect on their attitude not to be interested in working in the banking sector.

H1: Knowledge of employment in the banking sector has a positive effect on attitudes not to be interested in working in the banking sector.

Attitudes towards an object have a positive effect on an intention (Duffett, 2015; Mohaidin, Wei, \& Murshid, 2017; Rahman, Ebrahim, \& Rahman, 2017; Shah \& Soomro, 2017; Teng \& Wang, 2015). An intention is an excuse, and that reason also forms an attitude (Goetz, 2015). From several studies that have been done before, in this study the following hypotheses are arranged.

$\mathrm{H} 2$ : The attitude of respondents to not being interested in working in the sharia banking sector has a positive effect on the intention not to work in the sharia banking sector.

From the two hypotheses, the research model compiled as follows:

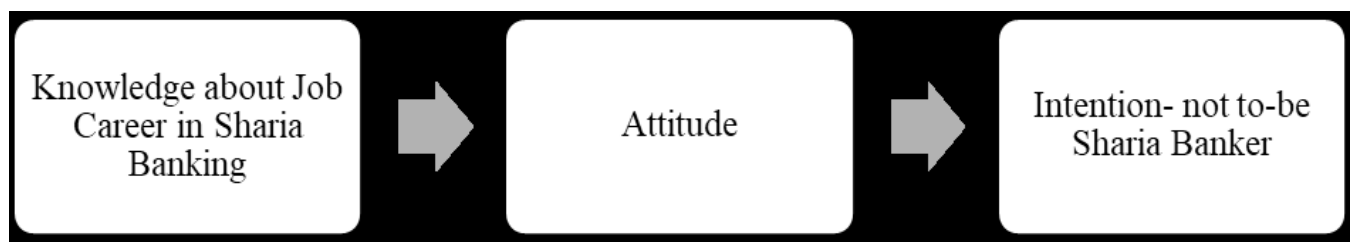

Figure 1. Research Model

\section{RESULT AND DISCUSSION}

The tests carried out in this study used SPSS because this tool was capable enough to execute and solve the research problems raised in this paper. Before the regression test was taken to prove the hypothesis, this study has passed the classic assumption test, such as normality and multicollinearity tests so regression test can be taken for the next stage.

The first test aims to test the first hypothesis, namely the knowledge of respondents about the conditions of working careers in sharia banking in the era of disruption affecting the attitude of respondents not to work in sharia banking as their future career. While the second test aims to test the second hypothesis, namely the t-Test of respondents to the working conditions of sharia banking career in the era of disruption has an effect on the intention not to be a sharia banker. The first and second test results are presented in Table 4. 
In the first test, the value of $\mathrm{R}$ was 0.512 which is the correlation between the knowledge variables regarding the career of sharia banking jobs in the era of disruption and attitudes towards the banking career in the era of disruption. Correlation values are categorized as being moderate and positive values are indicated as the direction of positive relationships. The results of the correlation testing are interpreted that the more respondent knows about the condition of sharia banking in the disruption era, the higher their attitude not to be a banker.

$\mathrm{R}^{2}$ is the percentage of the variation of the dependent variable described by the independent variable. If the value of $\mathrm{R}^{2}$ is 1 , it means that the dependent variable is fully described by the independent variable. In testing the first hypothesis, the $\mathrm{R}^{2}$ value is 0.263 . From these results, it can be interpreted that $26.3 \%$ of attitudes are explained by knowledge variables, while $73.7 \%$ is explained by other variables.

The t-test was carried out for two hypothesis testing. From the regression test for the first hypothesis, obtained a regression coefficient of 0.523 with a value of $t$ arithmetic 6,423 with a significance value of 0,000 and have a significant degree of $5 \%(0.05)$. So, it can be interpreted that knowledge of the career of Sharia banking work in the era of disruption has an effect on attitudes.

The results of this test are in line with previous studies. The attitude formation of an object is influenced by related knowledge about it (Agueria et al., 2018; Cheah et al., 2015; Hinduan et al., 2013). This makes a discussion that if a marketer wants to change a person's positive attitude, then one way that can be taken is to channel a lot of knowledge in the form of information relating to it.

For universities offering sharia banking programs, the form of socialization is to block negative information which is unnecessary such as there is no physical bank's office in the future which means there will be no more bank office needed. Some steps can be taken by the manager of the sharia banking study program: First, with a consumer approach. Information that blocked the issue that the prospects for financial labor must be addressed, such as ensuring that learning materials in sharia banking remain relevant even though some banks begin to reduce their employees. On the other hand, several Fintech start-up companies began to emerge and needed workers who were experts in the financial sector. Sharia Fintech began to appear to answer needs.

Second, with a product approach. With the existence of a financial industry that continues to grow and change rapidly, the campus must be able to respond to the market needs of employers in the field of sharia finance quickly. This is intended so that the campus can create a curriculum that can provide the skills needed in a rapidly changing financial world. The curriculum should be arranged futuristically.

This research also provides insight for the students who are studying in the sharia banking program. The students are hoped to always know and updating the changes of needs of the labor market. By knowing the latest updates, the students will prepare the knowledge and skills needed.

The second hypothesis examines the attitude of the respondent to have a positive effect on the intention not to be a sharia banker. The value of $\mathrm{R}$ in the second test is 0.509 which categorized as a medium value. Positive values in this correlation test world as the direction of a positive relationship. From these result, a conclusion is obtained that the 
attitude to not interested to be a sharia banker has a positive effect on the intention not to be a sharia banker.

From the second test, the value of $\mathrm{R}^{2}$ is 0.259 . It can be interpreted that $25.9 \%$ of the intention not to be a sharia banker is explained by attitudes, while $74.1 \%$ is explained by other variables. The result of the t-test in the second test, a regression coefficient value is 0.509 which was obtained with a t-value of 6.457 and a significance value of 0.000 . So, it can be interpreted that the attitude influences the intention not to be a sharia banker in the era of disruption.

This result of hypothesis testing is in line with the previous studies, namely, the intention is predicted by attitude (Duffett, 2015; Mohaidin et al., 2017; Rahman et al., 2017; Shah \& Soomro, 2017; Teng \& Wang, 2015). The study of intentions is very important for stakeholders because the intention is one of the strongest predictors to form behavior, in this case, the behavior to be a sharia banker.

For universities that offering sharia banking programs, the study of intention is important because the intention to be a banker has an effect on the intention to continue the study in the field that is in accordance with the desired career. The universities must take initiative in creating intentions in potential customers by forming attitudes for the students. In addition, universities must also examine further other factors that shape intention.

The summary of the calculation results for two hypotheses, starting from determinant coefficient and adjusted $\mathrm{R}$ square, Result of the t-test, and $\mathrm{F}$ Test are presented in Table 4 below:

Table 4. Determinant Coefficient and Adjusted R Square, Result of t-test, and F-test

\begin{tabular}{lrr}
\hline & $\begin{array}{c}\text { Knowledge about Job } \\
\text { Career in Sharia Banking }\end{array}$ & Attitude \\
\hline Determinant Coefficient and Adjusted R Square & & \\
\hline R & 0.512 & 0.509 \\
R2 & 0.263 & 0.259 \\
Adjusted R Square & 0.250 & 0.253 \\
\hline Result of t-Test & & \\
\hline Standardized Coefficient Beta & 0.523 & 0.509 \\
T & 6.423 & 6.457 \\
Sig. & $0.000^{*}$ & $0.000^{*}$ \\
\hline Result of F test & & \\
\hline F & 21.012 & 41.691 \\
Sig. & $0.000^{*}$ & $0.000^{*}$ \\
\hline
\end{tabular}

*Significant (Sig.<0.05)

Because there are intervening variables in this research model, a mediation test is conducted to find out whether there is a mediating relationship among the variables constructed in this study. Mediating variables in this research are very important to look 
for (Baron \& Kenny, 1986) because of the active intervention organism between stimuli and responses. The main idea in this study that the impact of knowledge as stimuli are the response in the form of intention.

The mediation test is carried out in several stages. First, this test examines the effect of knowledge about the career of sharia banking sector jobs in the era of disruption in the attitude of respondents. Testing is done by regression test so that the equation is obtained as follows.

$$
\mathrm{Y}=0,523 x
$$

By looking at the beta coefficients, it can be seen that the knowledge variable on the career of sharia banking jobs in the disruption era has a regression coefficient of 0.523 with a significant value of 0,000 smaller than 0.005 .

The first requirement for fulfilling mediation is an independent variable that is required to significantly influence the mediator variable with the regression coefficient $\neq 0$ (Baron \& Kenny, 1986) so from the result of the calculation, the first conditions for achieving mediation are fulfilled.

The second stage of mediation test is to do a variable attitude regression test on the intention not to be a Sharia banker in the era of disruption. From the test results, the equation is as follows.

$$
\mathrm{Y}=0,509 \mathrm{x}
$$

From the results of those tests, beta variable coefficient attitudes are 0.509 with a significant value of 0,000 and less than 0.005 . This stage also tests the regression of knowledge variables on the conditions of sharia banking employment in the era of disruption to the intention to be a banker with the results of the equation as follows.

$$
\mathrm{Y}=0,069 \mathrm{x}
$$

With such results, it can be concluded that the beta variable coefficient career knowledge of sharia banking jobs in the disrupted era is 0.069 with a significant value of 0,000 smaller than 0,000 . The results of the regression test between the three variables are presented in Table 5.

Table 5. The Result of the Mediation Test with Linear Regression Test

\begin{tabular}{lccc}
\hline \multicolumn{1}{c}{ Direction } & Beta Coefficient & T & Sig \\
\hline Knowledge --> Attitude & 0.523 & 6.423 & $0.000^{*}$ \\
Attitude --> Intention & 0.509 & 6.457 & $0.000^{*}$ \\
Knowledge --> Intention & 0.069 & 4.157 & $0.000^{*}$ \\
\hline *Signifant $($ Sig $<0.05)$ & & &
\end{tabular}

*Significant (Sig. $<0.05$ )

The fourth stage in the mediation test is to do a multiple regression test of knowledge in the career of sharia banking in the era of disruption and attitude to the intention not to be a sharia banker. The test results are presented in Table 6 . 
Table 6. The Result of Mediation Test with Multiple Regression Test

\begin{tabular}{lrr}
\hline \multicolumn{1}{c}{ Direction } & Beta Coefficient & T \\
\hline Knowledge --> Intention & 0.058 & 2.945 \\
Attitude --> intention & 0.523 & 6.423 \\
\hline
\end{tabular}

From Table 6, it can be concluded that the knowledge and attitude variables have a positive and significant effect on the intention not to be a Sharia banker with beta coefficients of 0.058 and 0.523 respectively. Thus, the third requirement for achieving mediation is fulfilled (Baron \& Kenny, 1986).

From a series of mediation tests conducted, it can be interpreted that mediation occurred in this study. The mediation was categorized as partial mediation because the value of the effect of knowledge testing is lower than the effect of attitude on intention. In other words, partial mediation that occurs is detected from the reduced coefficient of an equation, but still significant.

The meaning of the results of this test is that knowledge can form intentions, but the effect is relatively smaller. The intention formed will be greater if existing knowledge can form attitudes at first. In this study, current knowledge about the conditions of working careers at banks will affect the students' intention not to be sharia bankers. The intention not to be a sharia banker will be greater when knowledge about the conditions of work careers at the bank has shaped the attitude of not become a sharia banker first.

Mediation test in this study also gives the meaning that attitude is an important study to be carried out because this affects greatly both to the intention and in the formation of behavior. Previous studies stated that attitude is a predictor in the formation of intention (Mohaidin et al., 2017; Rahman et al., 2017; Shah \& Soomro, 2017), so, sharia banking program marketers not only share information but also ensure that shared knowledge shapes attitudes.

Attitude can be in the form of verbal and non-verbal expressions, attitude changes behavior also changes (Rokeach, 1996). Sharia banking study program marketers must be able to detect both trends and conditions that will occur so that the right marketing program can immediately be formulated. In other words, the Sharia banking program manager must always do market sensing.

Intention can be shared with other people. It depends on the people in the group. Everyone in the group will support the formation to be something intended, every member also participates in maintaining the intention too. The phenomenon of I will if you will also apply (Velleman, 1997). It concludes that influencers in a group are very necessary to form an intention so that marketing programs can also be done by forming attitudes in consumer groups. In disruption era, the influencer can be made not only in the real world but also in the virtual world. Digital marketing can be used to form the influencer. This is more suitable to influence generation $\mathrm{Z}$ because they are a digital native.

\section{CONCLUSION}

In this study, the condition of banks in Indonesia has an effect on student's attitudes and intentions not to be a sharia banker. This kind of reality will certainly endanger 
universities offering sharia banking programs. After collecting data through an online survey, the writer found that students' knowledge about the conditions of work careers in Islamic banking affected their attitudes and intentions to not to be sharia bankers. This paper has several implications for managers of sharia banking programs, including the formulation of programs that are possible to run. Programs that can be used by managers of sharia banking study programs in two approaches, the consumer approach, and product approach.

In further research, other variables can certainly be added to predict attitudes and intentions so that the most influential factors can be known. The quantitative method used also causes this study to be unable to delve deeper into the uniqueness of the data which can certainly be more explored if added to the use of qualitative methods.

\section{BIBLIOGRAPHY}

Agueria, D. A., Terni, C., Baldovino, V. M., \& Civit, D. (2018). Food Safety Knowledge, Practices and Attitudes of Fishery Worker in Mar Del Plata, Argentina. Food Control. https://doi. org/10.1016/j.foodcont.2018.03.028.

Apriyani. (2016, Mei 4). Nasib Kantor Bank di Era Digital. Retrieved from http://infobanknews. com/nasib-kantor-bank-pada-era-digital/.

Baron, R. M., \& Kenny, D. A. (1986). The Moderator-Mediator Variable Distinction in Social The Moderator-Mediator Variable Distinction in Social Psychological Research: Conceptual, Strategic, and Statistical Considerations. Journal of Personality and Social Psychology, 51(6), 1173-1182.

Cheah, I., Liang, I. P., \& Liang, J. (2015). Marketing Intelligence \& Planning Article information : Marketing Intelligence \& Planning, 33(5), 763-783.

Cooper, D. R., \& Schindler, P. S. (2014). Business Research Methods (12th ed.). New York: Mc Graw Hill.

Duffett, R. G. (2015). Facebook Advertising's Influence on Intention-to-purchase and Purchase amongst Millennials. Internet Research, 25(4), 498-526. https://doi.org/10.1108/IntR-012014-0020.

Goetz, S. (2015). The Choice-Intention. American Philosophical Quarterly, 32(2), 177-185.

Hair, J. F., Black, W. C., Babin, B. J., Anderson, R. E., \& Tatham, R. L. (2006). Multivariate Data Analysis. Upper Saddle River, NJ: Pearson Prentice Hall.

Hartogh, G. D. (2014). The Authority of Intention. Ethics, 115(1), 6-34.

Hawkin, D. I., \& Mothersbough, D. L. (2014). Consumer Behavior (12th ed.). New York: Mc Graw Hill.

Hinduan, Z. R., Suherman, H., Pinxten, W. J. L., Alisjahbana, B., \& Hospers, H. J. (2013). HIVrelated Knowledge and Attitudes among Indonesian Prison Officers. International Journal of Prisoner Health, 9(2), 92-102. https://doi.org/10.1108/17449201311326961.

Laucereno, S. F. (2018, Maret 8). Jumlah Pegawai Bank Menyusut. Retrieved from https:// finance.detik.com/moneter/d-3904720/jumlah-pegawai-bank-menyusut.

Li, H., Zhang, Y., Tong, H., Tong, Q., \& Liu, D. (2011). Study on Psychological Crisis Evaluation Combining Factor Analysis and Neural Networks. Psychology, 02(02), 138-142.

Liputan6.com. (2018, April 30). Perbankan Syariah Jadi Program Studi Terfavorit Peserta SPAN PTKIN. Retrieved from https://www.liputan6.com/news/read/3495106/perbankansyariah-jadi-program-studi-terfavorit-peserta-span-ptkin.

Mohaidin, Z., Wei, K. T., \& Murshid, M. A. (2017). Factors Influencing the Tourists' Intention to Select Sustainable Tourism Destination: A Case Study of Penang, Malaysia. International 
Journal of Tourism Cities, 3(4), 442-465. https://doi.org/10.1108/IJTC-11-2016-0049.

Rahman, A., Ebrahim, A., \& Rahman, S. (2017). Consumers and Halal Cosmetic Products : Knowledge, Religiosity, Attitude and Intention. Journal of Islamic Marketing, 6(1), 1481. https://doi.org/10.1108/JIMA-09-2013-0068.

Rochmatin, L. (2018). Prodi Berbau Syariah Paling Diminati di Ujian Masuk PTKIN 2018. Retrieved from http://jogjapolitan.harianjogja.com/read/2018/05/23/512/917967/prodiberbau-syariah-paling-diminati-di-ujian-masuk-ptkin-2018.

Rokeach, M. (1996). American Association for Public Opinion Research. Public Opinion Quarterly, 60(4), 515-541.

Sekaran, U., \& Bougie, R. (2016). Research Methods for Business (7th ed.). West Susex: Willey.

Shah, N., \& Soomro, B. A. (2017). Investigating Entrepreneurial Intention among Public Sector University Students of Pakistan. Education+Training, 59(7/8), 841-855. https://doi. org/10.1108/ET-11-2016-0168.

Teng, C., \& Wang, Y. (2015). Decisional Factors Driving Organic Food Consumption Generation of Consumer Purchase Intentions. British Food Journal. https://doi.org/10.1108/BFJ-122013-0361.

Velleman, J. D. (1997). How To Share An Intention. Philosophy and Phenomenological Research, 57(1), 29-50. DOI: 102307/2953776. 